\title{
RACE AND NATION IN TWENTIETH- AND TWENTY-FIRST-CENTURY BRAZIL
}

\author{
Kia Lilly Caldwell \\ University of North Carolina-Chapel Hill
}

White Negritude: Race, Writing, and Brazilian Cultural Identity. By Alexandra Isfahani-Hammond. New York: Palgrave Macmillan, 2008. Pp. 194. \$69.95 cloth.

Mama Africa: Reinventing Blackness in Bahia. By Patricia de Santan Pinho. Durham, NC: Duke University Press, 2010. Pp. $x+266 . \$ 84.85$ cloth. $\$ 23.95$ paper.

Brazil's New Racial Politics. Edited by Bernd Reiter and Gladys L. Mitchell. Boulder, CO: Lynne Rienner, 2010. Pp. viii + 251. \$59.95 cloth.

Uneven Encounters: Making Race and Nation in Brazil and the United States. By Micol Seigel. Durham, NC: Duke University Press, 2009. Pp. xxii +386. $\$ 89.95$ cloth. $\$ 24.95$ paper.

These four books provide important insights into Brazilian racial dynamics from both traditional and contemporary perspectives. Each contributes to the recent surge in scholarship on race in Brazil and moves this scholarship in interesting and exciting new directions. Together, the books examine the ideologies of racial democracy, racism, and antiracism through various disciplinary and interdisciplinary methods, including literary, cultural, historical, and socialscience approaches. They also situate Brazilian racial dynamics in the context of twentieth- and twenty-first-century social and political dynamics, and they raise important questions about the roles of race and racism in Brazilian society.

Brazil's New Racial Politics was inspired by Michael Hanchard's edited volume Racial Politics in Contemporary Brazil (1999). Edited by political scientists Bernd Reiter and Gladys L. Mitchell, Brazil's New Racial Politics is an innovative and timely collection of multidisciplinary research by Brazil- and U.S.-based sociologists, anthropologists, political scientists, and scholars in the field of communication studies. Several contributors map the advent of affirmative action policies for Brazilians of African descent in the early 2000s, how governmental discourses and policies related to race have unfolded, and the impact of those changes on social and political dynamics in the country.

Seth Racusen, Mónica Treviño González, and Renato Emerson dos Santos examine these policies and university entry (preparatory) courses for black and poor students, illuminating the role of race in access to education and the challenges of creating public policies to combat racial inequalities. Racusen's masterful analysis of university admissions offers useful suggestions for improving the process of 
selecting students of African descent. Treviño provides important background on shifting forms and strategies of black mobilization, particularly among women; this mobilization has moved from ideological resistance to racial prejudice and discrimination to calling for the state to combat racism. Treviño finds that nongovernmental organizations (NGOs) have played an increasingly important role in developing policies such as affirmative action for Afro-Brazilians. At the same time, however, the lack of support from the broader public threatens the sustainability of these new measures.

Santos provides additional insights into the politics of race and higher education. His analysis of university entry courses focuses on Pré-Vestibular para Negros e Carentes (PVNC), a network for black and poor students established in Rio's Baixada Fluminense in the early 1990s. Santos traces such preparatory institutions to 1976 and to the inspiration of the renowned black activist Abdias do Nascimento and the Center of Brazil-Africa Studies. (Indeed, Nascimento and members of the Black Experimental Theatre first proposed affirmative action and other public policies to combat racism in the 1940s.') This background to recent developments is useful, as it makes clear the long-standing challenges that AfroBrazilians have faced in the effort to achieve educational equity, particularly at the postsecondary level.

Several essays in Brazil's New Racial Politics look instead at formal politics and political institutions. Mitchell focuses on how black voters perceive black candidates for electoral office. Using survey data from the cities of Salvador and São Paulo, she argues that voters who embrace blackness by identifying themselves as preto (black) or pardo (mixed race and/or brown) tend to vote for black candidates in higher numbers. This analysis challenges most scholarship on race and politics in Brazil by pointing to the existence of an untapped "black vote." Cloves Luiz Pereira Oliveira examines the 1996 election of Celso Pitta, the first black mayor of São Paulo, Brazil's largest city. Focusing on journalistic coverage of Pitta's campaign, Oliveira explores how race shaped perceptions of Pitta, despite his efforts to present himself as a deracialized candidate. Until now, there has been little scholarship on the topics treated by Mitchell and Oliveira, a fact that highlights the importance of their findings.

Sales Augusto dos Santos expands traditional notions of the political by exploring the role of rap artists as "new agents of the antiracism struggle" and how Brazil's racism is challenged by traditional black social movements, black parliamentarians, black intellectuals, black NGOs, and "conscious rap" (Reiter and Mitchell, 171). This broad-based focus contributes to scholarly and activist literature by avoiding the tendency to minimize or privilege the efficacy of any particular approach to racism.

Keisha Khan Perry, Angela Figueiredo, and Fernando Conceição explore the dynamics of race, gender, class, and politics in the city of Salvador, Bahia, problematizing its image as the most black city in Brazil. Perry explores the leadership

1. Sérgio da Silva Martins, Carlos Alberto Medeiros, and Elisa Larkin Nascimento, "Paving Paradise: The Road from 'Racial Democracy' to Affirmative Action in Brazil," Journal of Black Studies 34 (2000): 791. 
of black women in the Gamboa de Baixo neighborhood and the racialized and gendered implications of urban policies, particularly slum clearance and forced segregation. She also underscores how reconstruction projects involve the displacement of undesirable (read: poor and black) populations to achieve a modernist vision of the city. The significance of this analysis emerges when one considers how little has been written about the impact of urbanization practices on the black population of Salvador.

Figueiredo moves away from the pervasive focus in scholarly literature on lower-income Afro-Brazilians to make an important and unique contribution to our understanding of the relationship of race and class in Brazil. Through an examination of the forms of discrimination that middle-class Afro-Brazilians experience, Figueiredo illuminates how these more affluent blacks are perceived as out of place when they do not meet social expectations that equate blackness with poverty and low social status. When read together, the essays by Perry and Figueiredo help create a composite picture of the experiences and challenges that Afro-Brazilians face in the city of Salvador.

Conceição provides additional insights into racial dynamics in Salvador by exploring the municipal elections of 1985. He notes that the prominence of AfroBrazilian cultural groups (blocos afro) in this city has rarely translated into increased political power. This is illustrated by the low number of blacks elected to municipal office during the 1980s, despite the boom in black culture that had begun to take place. Conceição's sobering analysis highlights the disconnect between the increasing visibility of black bodies dancing in squares and avenues and the stalled inclusion of blacks as decision makers within the state apparatus (Reiter and Mitchell, 191).

The essays by Perry, Figueiredo, and Conceição provide important background for an understanding of the contributions and shortcomings of Patricia de Santana Pinho's Mama Africa: Reinventing Blackness in Bahia. This book examines black cultural politics in Salvador since the 1970s with a focus on the discourses and practices of Olodum and Ilê Aiyê, two of the city's most famous blocos afro. Pinho states in her introduction that her work engages three major debates in cultural studies related to blackness, black culture, and black identities: (1) the interpenetration of culture and politics, (2) essentialist versus antiessentialist theories of racial identities, and (3) the social constructedness of race. These debates frame Pinho's analysis and, at times, seem to be superimposed on the research data. For this, Mama Africa is theory heavy and reads primarily as a cultural studies text.

Pinho draws heavily on Paul Gilroy's notions of race, raciology, and racial essentialism to support her explanation of the discursive and symbolic dimensions of black cultural activism in Salvador. ${ }^{2}$ Her opening chapter details the myth of Mama Africa created mainly by blocos afro through an "ideal combination of appearance, essence, and tendencies" as expressed in and on particular black bodies (24), and seeks to locate their longing for an African motherland in a diasporic

2. Paul Gilroy, The Black Atlantic: Modernity and Double Consciousness (Cambridge, MA: Harvard University Press, 1993); Paul Gilroy, Against Race: Imagining Political Culture beyond the Color Line (Cambridge, MA: Belknap Press of Harvard University Press, 2000). 
context. This argument is consistent with Pinho's view that Ilê Aiyê, in particular, "has relied heavily on a naturalized understanding of the black body as the main marker of difference" (5). For Pinho, this "naturalized understanding" is closely linked to discourses and practices that essentialize blackness.

Pinho advocates an anti-antiessentialist stance as an alternative to the oftenpolarizing debate about racial essentialism and antiessentialism. However, Pinho fails to delineate clearly what anti-antiessentialism might involve. She also draws heavily on scholars such as Stuart Hall, Gilroy, and Kwame Anthony Appiah, who tend toward an antiessentialism rooted in poststructuralist concepts of identity. As a result, Mama Africa is ultimately more antiessentialist than antiantiessentialist.

One of the major shortcomings of Mama Africa is the failure fully to address the ways in which structural and discursive conditions and processes shape black life and black culture in the city of Salvador and in Brazil more generally. In many ways, the book focuses on culture to the neglect of a thorough discussion of the structural racism, social marginalization, and political disempowerment that Afro-Brazilians experience. Although Pinho's analysis of the myth of Mama Africa offers an important critique of black cultural politics, it fails to discuss recent redefinitions of black identity and culture in relation to the Afro-Brazilian population's long-standing struggle for racial equality. As a result, Pinho presents a very one-sided view of contemporary cultural movements, without giving adequate regard to how practices of racial domination-including racial democracy, mestiçagem (miscegenation), and whitening-shape and severely limit the options available to Afro-Brazilians in their attempts at self-definition and self-making. Nor does Pinho adequately address the impact of these practices on the dialectic of blackness and whiteness in Brazil. Given these gaps, it is useful to read Mama Africa with and against many of the essays in Brazil's New Racial Politics, particularly those by Reiter and Conceição. Whereas Reiter focuses on the social construction of whiteness and white privilege, Conceição contextualizes contemporary practices related to the commodification of black bodies in Salvador within a longer history of slavery and racialized social relations in the city.

White Negritude: Race, Writing, and Brazilian Cultural Identity, by Alexandra Isfahani-Hammond, provides an insightful and thought-provoking analysis of literary, abolitionist, and sociological texts by Jorge de Lima (1895-1953), Joaquim Nabuco (1849-1910), and Gilberto Freyre (1900-1987), centering on their treatment of race, history, and national identity. By placing texts of various genres alongside one another, Isfahani-Hammond highlights the role of white Brazilian intellectuals in crafting notions of race and racial democracy in the country. One of the key contributions of her study is its concept of white negritude as a practice by which white authors appropriate and represent black subjectivity in a Eurocentric manner.

White Negritude places Lima's work in a transnational context, comparing his poems with those of the white Puerto Rican Luis Palés Matos and the Afro-Cuban Nicolás Guillén. Isfahani-Hammond argues that Lima, from Brazil's northeast, depicts black-white relations in ways that reinforce the social and sexual relations of slavery. She notes that Lima's representation of the "master/slave encounter re- 
lies upon a conceptualization of powerful white masculinity and seductive black femininity" (21). Isfahani-Hammond further asserts that Lima's work exemplifies a patriarchal model of authorial representation that substantiates mestiçagem and "speaks for Afro-Brazilians while remaining 'genetically' untouched" (25). To this end, she contrasts the aesthetic appropriation of blackness by white authors such as Lima to the representations of "sociohistorical blackness" found in the works of black authors such as Francisco Solano Trinidade (39).

A gendered reading of poems by Lima and Palés Matos provides a critical framework for understanding how these authors produce a "dematerialized miscegenation" that is "predicated upon the erasure of women of color" (34). IsfahaniHammond also finds problematic gender erasures in Guillén's work, particularly in respect to his writing out of Cuban history the sexual exploitation of black women under slavery. Isfahani-Hammond notes that although the rape of black women has been used in narratives of national origin in Brazil and the Caribbean, there has been little recognition of forced interracial sex and miscegenation in official versions of U.S. history and national identity.

Isfahani-Hammond's analysis underscores similarities in the seignorial perspective found in Freyre's sociological texts and Lima's poetry. Freyre is perhaps best known for Casa-grande e senzala (1933), his treatise on racial and sexual relations in Brazilian plantation society. Isfahani-Hammond describes Freyre as a "white northeastern descendent of plantation masters who consumes and 'gives voice' to the experience of African slaves" (45). She also calls attention to Freyre's support of Lima, as evidenced in his "Preliminary Note" to Lima's Poemas negros, published in 1947. According to Isfahani-Hammond, Freyre's characterization of Lima as an "acclimated' white man in the tropics" reflects Freyre's figurative concept of mestiçagem, which allowed whites to adapt to Brazil's tropical climate without undergoing genetic modification. By placing Freyre and Lima in dialogue, Isfahani-Hammond offers important insights into both authors' conceptualizations of race and Brazilian cultural identity.

The final chapter of White Negritude focuses exclusively on Freyre. Drawing on Maria Lúcia Pallares-Burke's recent biography, Gilberto Freyre: Um vitoriano dos trópicos (2006), ${ }^{3}$ Isfahani-Hammond highlights problematic aspects of Freyre's work and, contrary to much scholarship, calls attention to Freyre's "ambivalent and opportunistic" incorporation of Franz Boas's ideas. As the founder of U.S. cultural anthropology, Boas has been credited with developing the modern idea of culture, thus moving the focus of academic research from race and innate racial differences to culture. ${ }^{4}$ Because Freyre studied at Columbia University with Boas, a number of scholars have postulated the latter's influence on Freyre's views of race and culture in Brazil. Isfahani-Hammond argues that elements of eugenics remain in Freyre's ideas and that Boas's work was a "flirtation" for him, much as were white supremacist organizations such as the Ku Klux Klan (127). Ultimately,

3. This work was reviewed by David Lehmann in "Gilberto Freyre: The Reassessment Continues," Latin American Research Review 43, no. 1 (2008): 208-218.

4. Lee D. Baker, From Savage to Negro: Anthropology and the Construction of Race, 1896-1954 (Berkeley: University of California Press, 1998). 
Isfahani-Hammond's novel analysis of Freyre places him in the company of other Brazilian writers and thinkers who developed forms of "exclusionary hybridism" centered on the erasure of black culture and black subjectivity (25).

Micol Seigel's Uneven Encounters: Making Race and Nation in Brazil and the United States differs from the previously discussed texts because of its emphasis on historical analysis and its explicit attempt to place Brazil's racial, cultural, and economic dynamics in a transnational framework. Through careful interrogation of the ways in which the concepts of race and nation have been shaped and reshaped in and by transnational exchanges, Seigel moves scholarship on race in Brazil in important new directions. Although Uneven Encounters takes on a wide variety of topics in an interesting and creative manner, at times its analysis seems a bit disjointed. As a result, it may be difficult for readers to make the transition from one topic or chapter to another.

Although comparative scholarship on race and racism in Brazil and the United States dates back to at least the early twentieth century, most researchers have given little regard to economic and cultural connections between the two countries. Seigel highlights the ways that race making and nation making are inextricably linked in both countries, thus emphasizing "lumpy" and asymmetrical linkages between them (92). She interrogates these issues through topics that might not readily appear relevant: coffee consumption in the United States, musical forms such as maxixe and jazz, performances of exoticized Brazilian identity in the United States, the transnational connections of São Paulo's black press, and efforts to erect statues in honor of black women. Seigel offers a wealth of documentation to support her analysis of each topic and nimbly addresses a wide array of issues from a historically grounded, yet multidisciplinary perspective.

Seigel's ingenious analysis of U.S. advertisements for Brazilian coffee highlights links between how this commodity was consumed in the United States in the early twentieth century and processes of gendering and racializing. Such practices of consumer citizenship were central to the development of a "racialized nationalism" that favored the United States both economically and politically (15). This line of reasoning runs throughout the book, as Seigel demonstrates how economic and cultural exchanges often served to benefit the United States while Brazilians, particularly those of African descent, reaped minimal benefits.

Seigel's analysis of musical forms further underscores how cultural exchanges unfolded among Brazil, the United States, and France in the early twentieth century. Seigel's discussion of maxixe as a precursor to jazz acts to destabilize the notion that U.S. African Americans were the sole originators of jazz and that the United States was its birthplace. Seigel notes, moreover, that maxixe, with its AfroBrazilian origins, was viewed in the United States as both a black form and a foreign form, thus demonstrating the complex interplay of imperialism and racism, even in the realm of culture. Although the book problematizes such exoticization, it also highlights the ways in which maxixe, jazz, and tango brought together musicians of African descent from various countries. This aspect of Seigel's work is particularly novel, as it demonstrates how music served to unite African diasporic communities across borders of nation, language, and culture. 